\title{
Dünyevî İktidarın Meşrûlaştırılmasında Dinî Bir Ritüelin Kullanılması: Kaçarlar ve Taziye
}

\author{
Using a Religious Ritual in Legitimizing the Secular Authority: \\ Qajars and Ta'zieh
}

\begin{abstract}
Akın KİREN*
$\ddot{\mathbf{O z}}$

Kerbelẩda Hz. Hüseyin ve onu destekleyenlerin Hicri 10 Muharrem 61 tarihinde (Miladi 680 yılında) başına gelenleri anmak için, X. yüzyılın ortalarında Bağdat'ta halka açık bir anma merasimi düzenlenmiştir. Ağıtlar yakılarak ve göğüsler dövülerek gerçekleştirilen bu anma yöntemi, daha sonra Şiîler tarafından bir ritüele dönüştürülmüş ve yaygın hale getirilmiştir. Taziye olarak anılan bu ritüel, On İki İmam Şiîliğini İran’n resmî dinini olarak belirleyen ve ülkede çoğunluğun kabul etmesini sağlayan Safeviler döneminde yeni bir içerik kazanmış, İran’a özgü bir forma dönüşmüştür. Kaçar iktidarında ise taziyeye gösterilen ilgi üst düzeye çıkmıştır. Özellikle Nasirüddin Şahı̉n saltanatında taziye devletten önemli bir destek görmüştür. Hatta iktidarın himayesinde bir etkinlik haline gelmiştir. Bu dönemde, başta başkent Tahran olmak üzere İran’n birçok yerinde coşkulu merasimler düzenlenmiştir. Bunun en büyük sebebi, kutsal yönetme haklarının sorgulanmaya başladığı XIX. yüzyılda, toplum ve siyasi elitler tarafından Kaçar monarşisine bir takım eleştiriler getiriliyor olmasıdır. Diğer çağdaş monarşiler gibi tebaanın sadakatini elde etmek ve yabancı diplomatların saygısını kazanmak için bazı ideolojik araçlara ihtiyaç duyan Kaçar yöneticileri, tarihi önemdeki dinî ritüele de başvurmuşlardır. Gösterilerin etkisini artırmak için hiçbir masraftan kaçınmamışlar, her yerde tekyeler açılmasını desteklemişlerdir. Üstelik Kaçar ailesi dışında başkentte ve vilayetlerdeki bazı elitler tarafından da bu destek sağlanmıştır. Toplumun farklı tabakalarından insanlar ise maddi olarak veya organizasyonlara beden güçleriyle katılarak dâhil olmuşlardır. Bu durum taziyeyi insanları bir araya getiren muazzam bir dayanışma projesine dönüştürmüştür. Bunun yanında, seyircilerin gösterilere aktif katılımları etkinliğin önemli bir yönüdür. Merasimlerin merkezinde, gösterinin kahramanıyla özdeşleşerek Hz. Hüseyin’in çektiği acıyı ve şehit olmasını hissetmeye çalışmak yer almaktadır. Böylece, taziye, seyircilere duygusal boşalma yaşatan emsalsiz etkisiyle potansiyel isyancı hisleri sönümleyen bir araç işlevi görmüş, kitlelerin yönlendirilmesinde ve kontrol altında tutulmasında önemli bir fonksiyona sahip olmuştur. Ayrıca, gösterilerde göğüs dövme eylemi gerçekleștirilirken Șah’a mersiyeler okunmaktaydı. Tüm bunlar, bir yandan toplumun birlik duygusunun artmasına ve İranlı kimliğinin yerleşmesine önemli ölçüde katkı sağlamış, diğer yandan da monarşi ile gösterileri organize ettiren ileri gelenlerin politik hâkimiyetlerini artırmıștır.
\end{abstract}

Anahtar Kelimeler: Kaçarlar, Taziye, İktidar, Meşrûiyet, Din, Ritüel

\footnotetext{
Yrd. Doç. Dr., İstanbul Arel Üniversitesi, İktisadi ve İdari Bilimler Fakültesi, Uluslararası İlişkiler (İngilizce) Bölümü, akinkiren@arel.edu.tr

Bu çalışmadaki İngilizce kaynakların bir kısmına erişebilmeme yardımcı olduğu için, Georgetown Üniversitesi'nden H.İ. Çağatay Özdemir'e teşekkürü borç bilirim.
} 


\begin{abstract}
In the middle of the tenth century, a public commemoration was held in Baghdad to commemorate the things happened to Imam Hussein, grandson of Prophet Mohammad, and his supporters in Karbala in 10 Muharram $61 \mathrm{HE}(680 \mathrm{CE})$. This way of remembrance which was performed by mourning for the dead and by beating of the chest was later transformed into a ritual by the Shi'ites and became widespread. In the period of the Safavids, who endorsed the Twelver Shiism as the official religion in Iran and gave rise to the mass conversion of the population to this belief, the ritual called ta'zieh gained a new content and came to be identified with Iran. The interest shown in the ta'zieh reached a peak in the Qajar rule. Especially during the reign of Naser al-Din Shah ta'zieh was widely supported by the state. It became an event under the auspices of the central government. In this period, mass ceremonies were held throughout Iran, particularly in the capital city Tehran. The most important reason for this is the fact that when the divine right of rule had begun to be questioned in the nineteenth century, the Qajar monarchy was being criticized by society and political elites. The rulers of the Qajars, who needed new ideological tools like other monarchies to gain loyalty of their subjects and to earn respect of foreign diplomats, have resorted to this historically important religious ritual. In order to increase the effectiveness of the ceremonies, they did not avoid any expenditure and supported the opening of takyehs across the country. Besides the royal family, some other notables in the capital and in the cities gave support to the exhibitions. Moreover, people from the different social stratums got involved in it with financial contributions or by working in activities require physical strength. It transformed ta'zieh into a unique solidarity project puts people together. Additionally, active participation of audiences is a sabstantial part of the ta'zieh. Trying to feel the pain and martyrdom of Hussein by overidentifying her/himself with the heroic characters is at the core of the performance. In this way, with its unrivaled impact of abreaction, ta'zieh functioned as a relieving instrument on potential rebellious feelings. Also people were reading poems to praise the Shah while they were beating their chests in the ceremonies. All these factors contributed to both strengthening feeling of unity and consolidating the Iranian identity in one hand. On the other hand, they helped increasing the political sovereignty of the monarchs and the elites who organized the ehhibitions.
\end{abstract}

Keywords: Qajars, Ta’zieh, Rulership, Legitimization, Religion, Ritual

"Muharrem ayında Kerbelẩdaki olayların hikâyesini yeniden inşa eden taziye geleneği, İran Şî̀liğinin özgün ve ayırt edici bir özelliğidir” (Daniel, 2006, s. 184).

\title{
Giriş
}

Nasirüddin Şah, Paris ve Londra gibi Avrupa başkentleri ile İstanbul ve Kahire gibi komşu merkezlere gitmiş diplomat ile devlet adamlarının raporlarından etkilenerek, 1867 yılında Tahran’ın yeniden yapılandırılması için bir komisyon kurulmasını istemişti (Gurney, 1992, s. 64). Daha sonra, şehir planlamasıyla ilgili bu girişim dâhilinde, Gülistan Sarayı́nın yanına görkemli bir tiyatro salonu yapılması talimatı verdi. Tekye-i Devlet adındaki bu abidevî yapı, Şah’ın 1873 yılında Avrupa seyahati sırasında gittiği Londra’da gördüğü Albert Hall binası model alınarak, dört binin üzerinde seyirci kapasitesi olacak şekilde inşa edilmişti. Bunun yanında, yine Nasirüddin 
Şah ve diğer Kaçar şahları dönemlerinde, başta Tahran olmak üzere İran’’n her yerinde çok sayıda tekye yapılmıştı. ${ }^{1}$

Tekye-i Devlet ve diğer tekyeler, daha ziyade Hz. Muhammed'in torunu, Hz. Ali'nin oğlu ve aynı zamanda On İki İmam Şiî inancına göre üçüncü imam olan Hz. Hüseyin'in Kerbelầda şehit edilmesi ve sonrasında gerçekleşen olayların dramatik bir tarzda sunumu şeklinde tanımlanabilecek taziye anmalarının gerçekleştirilmesi amacıyla yapılmıştır (Aghaie, 2004, s. 3046; Gurney, 1992, s. 64). ${ }^{2}$ Bunun sonucu, taziye anmaları iktidar desteğiyle organize edilen ve halkın toplu halde katılımının arttı̆̆ı bir faaliyete dönüşmüştür. Ayrıca, daha önce geleneksel olarak dindarların katkısıyla Muharrem ayının ilk on gününde gerçekleştirilirken, coşkusu iki aya yakın süren büyük organizasyonlar halini almıştır (Marashi, 2008, s. 39-41).

Taziyenin bu denli önem kazanması, toplumun iktidarlara olan sadakat bağının daha da güçlenmesini, dolayısıyla iktidar tarafından daha kolay yönlendirilme olasılığını artırmıştır. Yani, Şiî ritüeli olan taziye sayesinde, Kaçarlar (1796-1925) kendi iktidarlarını kapsamlı ve popüler düzeyde daha meşrû gösterebilmişlerdir.

\section{Teorik Çerçeve}

XIX. yüzyıl sonu ve XX. yüzyıl başlarında, Fransa ile İsviçre dışındaki bütün Avrupa'da ve Osmanlı İmparatorluğu ile İran gibi doğu toplumlarında monarşi hala geçerli devlet yönetim şekliydi (Hobsbawm, 2006, s. 328). Fakat milliyetçiliğin ve liberal düşüncenin etkisinin artmasıyla, hanedanların yönetme hakları tartışılmaya başlamıştı. Bu bağlamda, "kutsal hak"tan kaynaklanan geleneksel meşrûiyet kavramı zamanla toplumların ve siyasi elitlerin gözünde anlamını yitiriyordu. Doğal olarak, monarklar tebaanın sadakatini sağlamak için çeşitli ideolojik araçlara, Hobsbawm’ın deyimiyle (1993, s. 108) “yeni sadakat biçimlerine” ihtiyaç duydular. Söz konusu ülkelerin yöneticileri, mitler, semboller, değerler sistemi ve ortak hatıralar yoluyla alt ve orta sınıfları kapsamaya ve toplumun tüm tabakaları arasında ortak paydalar bulmaya çalıştılar. Yani, yeni bir topluluğun "hayal” edilmesini sağladılar (Anderson, 2006).

1 Türkçe'de tekke olarak kullanılan tekye kelimesi, zikir veya ders için toplanılan yer anlamına gelmektedir. İran'da, şehir içinde toplu yas törenleri yapılan basit bir meydana veya binlerce izleyiciyi alabilecek ve bizzat bu iş için hazırlanmış binalara bu isim verilmiştir. Peterson’a göre, kelimenin içeriği 1840'lardan itibaren ihtişam arz eder bir hal almıştır (Peterson, 1979, s. 64-65). Ayrıca, günümüzde tekye yerine hüseyniye tabiri de kullanılmaktadır. Ancak ikisi arasında, kompleksin her zaman açık olması ya da sadece Muharrem ayında açılması gibi bazı farklılıklar bulunmaktadır. Bkz. (Tusli, 1366; Bozorgnia, 1383).

2 Arapça bir kelime olan taziye, Türkçede ve Farsçada vefat eden kişinin anılması ve yakınlarına başsağlığı ziyaretinde bulunulması gibi anlamlarda kullanılmaktadır. Ancak, İran’da ve Şiî kültüründe daha özel bir anlam bulmuş, Kerbelâ şehitlerinin anılması ve sonrasında gerçekleşen bir dizi olayın sahnelenmesi amacıyla düzenlenen dinî törenin tanımı haline gelmiştir. Bugün bu kelimenin yerine daha ziyade ezadârî kelimesi kullanılmaktadır. Bununla birlikte, normal zamanlardaki diğer ölümler sonrası düzenlenen taziyelerde bile Kerbelâ hadisesi anılmaktadır... Diğer taraftan, esasında ritüel haline gelmiş bu törenin/gösterinin kökenleri İslâm öncesi İran kültürüne dayanmaktadır. İran'daki anma etkinliği, bu coğrafyadaki kültürlerin içinden gelen çeşitli ritüellerle birleşip (Mitra’nın, Zarir'in ve Siyavuş'un yaşadıklarına tutulan yaslardaki ritüeller) İran’a has bir hal almıştır (Mahani, 2013, s. 23-24). 
Selim Deringil, “Osmanlı İmparatorluğu’nda 'Geleneğin İcadı', 'Muhayyel Cemaat' ('Tasarlanmış Topluluk') ve Pan-İslâmizm” başlıklı makalesinde (2009), son dönem Osmanlı İmparatorluğu’nu Hobsbawm’n "geleneğin icadı" ve Anderson'ın "muhayyel cemaat" kavramları çerçevesinde incelemiş, "Pan-İslâmizm”i bu ikisi ışığında ele almıştır. Bu çalışmada da Kaçarların XIX. yüzyılın ikinci yarısında taziye gösterilerine gittikçe daha fazla önem vermelerinin, Hobsbawm ve Anderson’ın sundukları teorik araçların kullanımıyla özdeşlik gösterdiğine dikkat çekilecektir. Çalışmada Deringil'in kullandığı yöntemden esinlenilerek, Osmanlı İmparatorluğu’na komşu olan dönemin diğer bir doğu monarşisi Kaçar İranı’ndaki gelişmelere değinilecektir. Ancak Deringil'in çalışmasındaki Osmanlı örneğiyle belli bir dönemde uygulanan genel bir siyasete odaklanılmasından farklı olarak, İran'da başvurulan tek bir araç üzerinde durulacaktır. Zira adına ister Pan-İslâmizm diyelim isterse İttihâd-1 İslâm, ${ }^{3}$ 1870'lerin sonundan itibaren Osmanlı yönetiminin uyguladığı siyasetin benzerini İran'da görmek mümkün değildir. İran’n bu çalkantılı döneminde, topyekûn belirgin bir siyasetten ziyade tekil araçlardan istifade edilmiştir.

Diğer taraftan, özellikle İngilizce literatürde taziye gösterileri üzerine çok sayıda akademik çalışma bulunmaktadır. Bu çalışmalarda, kronolojik olarak ifade edersek, XVI. ve XVII. yüzyıllarda Safevi Devleti’nin (1501-1722) katkısına, Nadir Şah döneminde (1736-1747) bu geleneğin geriletilmesine, Zend Hanedanı sırasında yeniden gelişim göstermesine, ardından Kaçarlarla birlikte gösterilen ilginin doruğa ulaşmasına, 1925 sonrası Pehlevi yönetiminde ikinci defa gerilemesine ve nihayet 1979 Devrimi'nin ardından popülaritenin bir kez daha artmasına işaret edilmektedir. Çalışmada; bu dönemler arasından gösterilerin ülkenin her tarafında yaygın ve etkin olarak sergilendiği Kaçar dönemine 1şık tutulacaktır. Zira Kaçar döneminde (17961925), özellikle de Nasirüddin Şah zamanında (1848-1896), taziye, devlet destekli teatral bir eylem olarak birlik duygusunun artırılmasına katkı sağlamanın yanında, yönetimin dinî ve siyasî meşrûiyet iddiasını güçlendirecek şekilde kullanılmıştır. Bu nedenle, Kaçar yönetimi himayesinde eskisinden daha şaşaalı sergilenen Kerbelâ anmalarının, yüzyılın ortasından itibaren iktidarlar tarafından nasıl araçsallaştırıldığı incelenecektir.

\section{Taziye Gösterileri}

Taziye, İran'da düzenlenen tüm dinî törenler arasında en etkilisidir ve hicri takvimin birinci ayı olan Muharrem'in ilk on gününde gerçekleştirilir. ${ }^{4} \mathrm{Bu}$ on günlük süredeki tüm anma etkinlikleri

3 Osmanlı İmparatorluğu’nda Müslümanların birliğinin sağlanması düşüncesinden hareketle özellikle II. Abdülhamid döneminde izlenen siyasetin adlandırılması üzerine farklı yaklaşımlar bulunmaktadır. Bu yaklaşımların genel hatlarıyla değerlendirilmesi ve farklı bir yorum için bkz. (Kiren, 2017, s. 41-55).

4 Taziye ritüelinin önemli bazı unsurları bulunmaktadır. Bunlardan biri deste-i ezâ-dâri denilen geçit alayıdır. Bu alay sadece bir cenaze alayı değildir. Aynı zamanda gösterişli-tantanalı bir törendir. Taziyedeki oyuncular ve seyirciler; acılarını, sarıklarını çözüp gömleklerini yırtarak ve kan gelinceye kadar gittikçe artan şiddetle çıplak göğüslerine vurarak dışa vururlar. Bunun yanında, Türkiye'deki meddahlık gibi, İran’da nakkalın (rûze hân, perde-dâr, pişkan, şemâil-gerdân) taziyenin gelişiminde önemli bir payı vardır. Bu kişi, anlattığı hikâye içinde yer verdiği efsanelerle taziyenin tesirini artırır (And, 2012, s. 102-103). Ayrıca, birçok ritüelde olduğu gibi, taziyede de güçlü bir edebi yön bulunmaktadır. Hatta esasında İran taziyesi gücünü büyük oranda Muharrem ayı boyunca süren ve rûze hâni denilen edebi gelenekten almaktadır. Söz konusu gelenek, Hüseyin Vaiz Keşifi'nin yazdığı “Ravzatü’l Şüheda (Şehitler Bahçesi)” adlı şiirle birlikte XVI. yüzyıldan itibaren ön plana çıkmıştır. Daha sonra da taziyenin ayrılmaz bir unsuruna dönüşmüștür (Asani, 2015, s. 157). 
arasında, bölgeden bölgeye farklılık gösteren birçok geleneğe yer verilmektedir. Ancak bunların en yaygın ve ortak olanı; yevm-i aşûrâ, yevm-i katl veya rûz-ı katl olarak adlandırılan ayın onu (aşure) ve bunun bir gün öncesinde (tasu’â) gerçekleştirilen dramatik gösterilerdir. Bu iki günde insanların hassasiyetleri en üst noktaya çıkmakta ve ülke çapında her yerde organizasyonlar düzenlenmektedir (Daniel, 2006, s. 183). 1866 ile 1881 yılları arasında İngiliz telgraf şirketinin doktoru olarak İran'da bulunan Wills, Şiraz'da katıldığı taziye gösterilerinden bahsederken, küçük bir köyde bile mutlaka taziye gerçekleştirildiğine dikkat çekmiştir. Wills (1891, s. 279-283), Şiraz Valisi Şehzade Zillu’l Sultan’n, sarayının bahçesinde büyük çapta bir taziye organize ettirdiğini, aynı bölgede diğer varlıklı kişilerin ise daha küçük ölçekte de olsa gösterilere öncülük ettiklerini belirtmiştir.

Taziye, Hz. Hüseyin ile taraftarlarının Emevi halifesi Muaviye’nin oğlu I. Yezid’e bağlı güçler tarafından 10 Muharrem 61 (680) tarihinde Kerbelầda acımasızca muamelelere maruz bırakılmalarının yeniden canlandırılarak anılması anlamına gelmektedir. ${ }^{5} \mathrm{Bu}$ nedenle, yaşanan bazı olayların taklit ve temsil edilmesi ya da bunun için yas tutulması fikrine dayanır (Daniel, 2006, s. 184). Günümüzde de Şiî toplumlarında görülmekte olan şekliyle taziye, aslında X. yüzyılın ortalarında Bağdat’ta Hz. Hüseyin’i anmak için halka açık olarak başlayan anma merasimleri geleneğinin son aşamasıdır. Katılımcıları yüzleri siyaha boyanmış ve saçı-başı dağınık haldeki Şî̂ler olan bu ilk taziyede, inilti içinde ağıtlar yakılmış, göğüsler dövülmüştür (Pettys, 1981, s. 342; Mahani, 2013, s. 23).

Zamanla taziye Şiî inancında müstesna bir ritüele dönüşmüştür. İslâm kültürü içinde geniş kitlelerin katılımıyla icra edilen tek teatral seremoni olan taziye, yas, acı çekme, dövünme, ağlayıp inleme ve oruç tutma gibi unsurları içermektedir. Bununla birlikte, Kerbelâ ve sonrasında yaşanan olaylardan öne çıkanların ayrı ayrı canlandırıldığı, birbirlerinden farklı içerikte taziyeler bulunmaktadır. Hz. Hüseyin'in şehit edilmesiyle ilgili yazılan senaryo dışında, örneğin, “Şam Pazarı Taziyesi (Taziye-yi Bâzar-ı Şam)"nde aşure günü tutsak edilenlerin yaşadıkları dram sergilenmektedir. Ancak buna karşılık, doğrudan Kerbelâyla ilişkili olmayan taziyeler de vardır. Mesela, "Taziye-yi Vefât-ı Peygamber"de Hz. Muhammed'in hayatını kaybetmesi, "Taziye-yi Şehadet-i Hz. Ali"de Hz. Ali’nin şehit edilmesi gibi canlandırmalar yapılmaktadır (Mahani, 2013, s. 28). Dolayısıyla, And'ın işaret ettiği şekilde (2012, s. 39), Muharrem anmalarında eksen kişi Hz. Hüseyin olsa da; diğer şehit ve dinî önderler için de taziyeler hazırlanması, söz konusu ritüelin örnek üzerine gelişen geniş bir birikim olduğunu göstermektedir.

Taziye gösterilerinde seyircilerin aktif katılımları etkinliğin önemli bir yönüdür. Kaynaklarda seyircilerin sanki düğüne gider gibi hazırlık yapıp faaliyete iştirak ettikleri ifade edilmektedir. Gösterinin kahramanıyla özdeşleşerek Hz. Hüseyin’in çektiği acıyı ve şehit olmasını hissetmeye çalışmak merasimin merkezindeki husustur. William Beeman, seyircilerin gösterinin hem içinde

Bilindiği gibi, Emevî halifesi Muaviye’nin hayatını kaybetmesinden sonra, oğlu Yezid Şam’da kendisini halife ilan etmiş ve burada bulunan Müslümanlardan biat almıştı. Buna karşılık, O’nun hilafetini onaylamayan Müslümanlar da Hz. Hüseyin’in başa geçmesini istiyorlardı. Hz. Hüseyin, Kûfe'deki Müslümanlar tarafından hilafeti üstlenmesi için buraya davet edilmişti. Ancak Kûfe’ye giderken Kerbelâda Yezid’e bağlı birlikler tarafından kuşatıldı ve O’na biat etmesi istendi. Bunu kabul etmeyince de yanında bulunan kendisine sadık küçük bir grupla birlikte acı şekilde öldürüldü. Bkz. (Ateş, 1987, s. 634-640; Kılıç, 2013, s. 513). 
hem de dışında olduklarını belirtmektedir. Beeman’a göre (2015, s. 52), "Katıllmcılar ve izleyiciler taziyeyi bir tiyatro olarak görmezler, daha çok dinî bir yas olarak algllarlar. Ancak yine de; taziye kesinlikle birçok teatral uygulamayı içeren bir gösteridir". Gösterilerde çoğu zaman kendilerinden geçen seyirciler, Hz. Hüseyin’e ve yandaşlarına yardım etmeye çalışıı̧lar ve düşmanlarının onlara saldırmalarını engellemişlerdir. Bu durum ironik olarak gösterinin kötü karakterlerini sergileyen oyuncuları fiziksel tehdit altında bırakmıştır (Chelkowski, 1985, s. 24).

Diğer taraftan, aslında Kerbelâ hadisesi sebebiyle yas tutulması yalnızca Şiảya özel bir husus değildir. Neredeyse tüm Müslümanlar bu olayı geçmişte yaşanan acı bir hatıra olarak kabul etmekte, Endonezyàdan Jamaika’ya İslâm toplumlarında söz konusu tarihlerde değişik anma etkinlikleri düzenlenmektedir. Hatta bu durumdan İslâm dışı bazı gruplar dahi etkilenmişlerdir. Örneğin Hindular arasındaki soylu Mohyal Brahmin topluluğu Muharrem ayında bir takım kutlamalar yapmaktadır (And, 2012, s. 47, 57). ${ }^{6}$ Ancak, anmalar ve gösteriler Şî̂ toplumlar arasında daha titiz ve özenli olarak gerçekleştirilmekte ve sahnelenmektedir. Belki de bunun sebebi, olayın Şiîler tarafından yalnızca ve açık biçimde politik gücün gasp edilmesinin hikâyesi olarak değil, "doğruluktan sapmama ve iyi ile kötü arasındaki evrensel mücadeleyi temsil etme" şeklinde algılanıyor olmasıdır (Asani, 2015, s. 152).

\section{Taziye ve Millî Duygular}

İran'da milliyetçiliğin doğuş ve gelişme zamanına dair farklı görüşler bulunmaktadır. Fakat bir devlet ideolojisi olarak ortaya çıkmasının ve geniş kitlelerce kabul görmesinin, önce XX. yüzyıl başındaki Meşrûtiyet Hareketi (1906) ve ardından Rıza Şah Pehlevi (1925-1941) dönemlerinde gerçekleştiği kabul edilir (Arjomand, 2016). Diğer taraftan, Banani’nin yerinde ifadesiyle (1961, s. 14), Sünnî komşulara karşı Şiî bir güç olarak asırlarca süren karşı duruş, İran’ı zaten modern milliyetçiliği kabul etmeye hazır hale getirmiştir. Bir diğer deyişle, Şiîlik, İran'da milliyetçiliğin kurgulanmasında verimli bir alan açmıştır (Kamrava, 1990, s. 125).

Milliyetçiliğin İran’da ortaya çımasında iki faktör önemli rol oynamıştır. Bunlardan birincisi toprak birliği (coğrafi), diğeri ise dinî kimliktir:

İran kavramı, dolayısıyla bir İranlı algısı, Avrupa'da modern devletin ortaya çıkmasından önce de vard. İran-zemin veya İran-şehr gibi terimler, X. yüzyıldan beri, hatta Gnoli’nin (1989) tespit ettiği gibi daha Sasani döneminde (224-651) bile kullanılmaktaydı. İranlı şair Firdevsỉnin (940-1020) meşhur Şehnâme’sinde İran kelimesine binin üzerinde gönderme yapılmıştı (Kashani-Sabet, 1999, s. 15-19). Bu nedenle, İranın coğrafi bir bölge olarak tanımlanması çok eskilere dayanmaktadır ve modern zamanlarda İranlı kimliğinin yerleşmesi için güçlü bir altyapı oluşturmuştur. ${ }^{7}$

6 Asani (2015, s. 156), Hindistan'da ekonomik çlkarları bulunan İngilizler sayesinde taziyenin 1845'ten itibaren Asya dışına da taşındığına işaret etmektedir. Gruplar halinde Karayipler’e giden Hindistanlı Şîiler beraberlerinde taziye ritüelini götürmüşlerdi. Trinidad’a yerleşen bir grup Şiî, bunu aralarındaki sosyal bağı artıran ve "anavatanı" hatırlatan bir araç olarak görmüştü.

7 Buna karşılık, Kaçar dönemine dair kaynakların bir bölümü bu dönemde ülkenin siyasi yapısını konfederasyon olarak nitelendirmektedir. Bu kaynaklarda, Şah’ın otoritesinin merkez dışında tam olarak hissedilmediği ve diğer 
İkincisi, Safevi Devleti’nin kurulmasının ardından çok sayıda insanın zorla ya da gönüllü olarak Şiî inancını benimsemesi ülkeyi etrafındaki Sünnî dünyadan büyük ölçüde izole etmiştir (Fisher, 1980, s. 28; Neuman, 2006). Şî̀ İran (Safevi Devleti), XVI. yüzyıl sonrasında, kuzeyde Özbekler, batıda Osmanlılar ve doğuda Peştun ile Moğollardan oluşan Sünnî gruplar tarafından sarılmış durumdaydı. Bu nedenle, Şiî bir devletin sağlam temeller üzerine yerleștirilmesi için Safeviler olağanüstü gayret göstermişlerdi (Rahimi, 2013, s. 56). Dolayısıyla, çoğu Şî̂liği benimsemiş İranlıları çevresindeki topluluklardan ayrıştıran rolüyle, Şî̂ inancı da bir çeşit tutkal vazifesi görmüş, insanlara duygudaşlık vermiş ve modern öncesi zamanlarda ortak bir bilinç oluşumunu mümkün kılmıştı. ${ }^{8}$ Bu bilinç, İran olarak tanımlanan coğrafyanın her yerinde aynı olmasa bile merkezin doğrudan kontrol edebildiği yerlerde oldukça etkiliydi. ${ }^{9}$ Böylelikle teritoryal ve kültürel farkındalık ülkede dinî kimlikle bütünleşiyordu. Yani bir anlamda, Şî̂ kimliği coğrafi bilinçle birlikte toplumun büyük kısmını kenetleyen unsur haline gelmişti. ${ }^{10}$

$\mathrm{Bu}$ birleşmenin ögeleri arasında, X. yüzyıldan beri süregelen yas ritüelinin Safevi şahlarının teşviki ve yer yer ileri gelenlerin desteğiyle yeni sembol ile adetleri içererek zenginleşmesi yer almaktadır. İlk üç halife (Hz. Ebu Bekir, Hz. Ömer ve Hz. Osman), Muaviye, oğlu Yezid ve onların taraftarlarının kötülenmesi vb. uygulamalarla, taziye aracılığıla etkin bir şekilde "Sünnî öteki" yaratılmıştır. ${ }^{11}$ Pettys (1981, s. 342), İran’da "millet"in yeniden şekillenmesinin ve Şiîliğin resmi inanç olarak yerleştirilmesinin, İran’a özgü bir taziyenin gelişmesini sağladığını ifade etmiştir.

bölgelerde toplumu genellikle büyük aşiret reislerinin yönettiği ifade edilmektedir. Aşiret reisleri, çoğu zaman vali rütbesi taşımışlar, bazı uzak bölgelerde kontrolü neredeyse tamamen bunlar elde bulundurmuşlardı. Görünüşte Şah tarafından atanmışlar, fakat uygulamada, Şahlar zaten doğal lider olan bu kişileri atamak zorunda kalmışlardı. Dolayısıyla, ademi-merkeziyetçi bir yapı İran politik hayatını belirlemişti. Ükenin her bölgesinde aynı toprak tahayyülünün olduğunu ifade etmek mümkün değildir. Bkz (Kiren, 2017, s. 58).

8 İranlı kimliğinin ortaya çıkışı ve gelişimine dair yürütülen akademik tartışmaların genel bir değerlendirmesi için bkz. (Matin-Asgari, 2012).

9 Burada bütün İran’ın Şiîliği kabul etmiş olduğunu veya aynı duygudaşlık içerisinde olduğunu kastetmiyoruz. Ne Safevi ne de Kaçar döneminde, bugün de olduğu gibi, İran'da nüfusun tamamı Şiî-Müslüman değildi. Veya kendisini merkezi güçle aynı kimliğe sahip görmüyordu. Hatta belki de merkezi kimliğin farkında bile değildi. Söz konusu coğrafyada, Sünnî-Müslüman, Hıristiyan, Yahudi, Zoroastri, Asuri gibi diğer inanç grupları da bulunmaktaydı. Çalışmada, taziyenin bir ritüel olarak daha ziyade Şiîler tarafından gerçekleştiriliyor olması ve ülkede Kaçar dönemine gelindiğinde çoğunluğu Şiîlerin oluşturması gibi nedenlerden ötürü, Şiî gruplar-iktidar ilişkisi öne çıkartılmıştır... İran'da azınlıkların durumu ve devletle ilişkileri konusunda şu kaynaklara bakılabilir (Elling, 2013; Saleh, 2013).

10 Abrahamian, İranlı kimliğinin oluşmasında İslâm öncesi ve İslâmî dönemin her ikisinin de etkili olmasının, annebabaların çocuklarına verdikleri isimlerden anlaşılabileceğine dikkat çekmiştir. Ülkede verilen isimlerde, "Şiîliğin etkisi Ali, Mehdi, Rıza, Hüseyin, Hasan ve Fatima; şair Firdevsi ve onun Şehname’si aracıllğıyla antik İan’ın etkisi İsfendiyar, Rüstem, Suhrab, Erdeșir, Gâve (Kâve), Behram ve Atussa isimlerinde görülmektedir." (Abrahamian, 2014, s. 2); Öte yandan, çalışmanın başlangıcında Hobsbawm ve Anderson'a atıf yaparak milliyetçilik kuramlarından modernist yaklaşımı benimsememize rağmen, "İran” kavramının Sasanilere ve Firdevsìye kadar götürülebileceğini ifade ederek "primordialist (ilkçi)" yaklaşımlara yaklaştığımız düşünülebilir. Bunu ifade etmekteki amacımız, kavramın tarihsel varlığının katkısına değinmektir. Bilindiği gibi, ilkçi yaklaşımların ortak özelliği, milletleri "doğal yapılar" olarak görmeleridir. Oysa burada, doğal olmayan, yapay bir uygulamanın, modernleşme gayretleri içerisindeki etkisini incelemekteyiz. Dolayısıyla, esasen modernist yaklaşımı kabul etmekteyiz... Milliyetçilik kuramlarına eleştirel bir bakış için bkz. (Özkırımlı, 1999).

11 Örneğin, XIX. yüzyıl sonunda, ikinci halife Hz. Ömer'in öldürülmesi alaycı bir taziyede kukla yakılarak konu edilmiştir (Pettys, 1981, s. 353). 
Ayrıca, Safeviler, Peygamber soyundan geldikleri iddiasına benzer argümanları da kullanarak kendilerine bir çeşit meşrûiyet sağlamışlar, ${ }^{12}$ özellikle Osmanlılar karşısında Şî̂ bir İranlı bütünlügü oluşturmuşlardı. Onlardan sonra arada kısa bir süre kesintiye uğrasa da taziye gittikçe daha popüler hale gelmiş, XIX. yüzyılda İran sınırları boyunca yaygın bir eyleme dönüşüp Kaçar şahlarının himayesi altına girmiştir (Daniel, 2006, s. 184).

Öte yandan, taziyenin iktidarlarca açıkça desteklenmesi, Rus ve İngiliz yayılması karşısında merkezi kontrolü sağlamaya çalışan Kaçarların ülkeyi modernleştirme çabalarıyla aynı tarihlere denk düşmektedir. Lambton’a göre (1988, s. 200), XIX. yüzyılda Batı teknolojisi İran’a girdikçe; idari yapı otoritesini genişletmeye çalışırken eski dinî aidiyetlerin yerini "millî” aidiyet almaya başlamıştır. Ancak bu millîlik, henüz tam anlamıyla modern bir milliyetçilik değil, din ile yoğrulmuş bir olgu idi. Bu dönemde, Şah hâlâ bir "İslâm Padişahı", İran ise "İslâm toprağı" kabul edilmekteydi. Böyle bir ortamda, daha fazla kişi tarafından daha coşkulu kutlanan taziye gösterileri, dinî ve "millî” duyguların dışa vurumu olarak görülebilir. ${ }^{13}$

Sonuç olarak, taziyenin başlangıçta Emevilere (Araplara), daha sonra XVI. yüzyıldan itibaren Osmanlılara (ve diğer Sünnî komşulara), nihayet XIX. yüzyılla birlikte bir de Batılı devletlere karşı birlik sağlamak amacıyla kullanıldığını söylemek mümkündür. Pettys bunu, “Taziye isyandır! Arap boyunduruğuna ve Sünnî egemenliğine karşı başkaldırışın, cüretkâr bir araç yoluyla dile getirilmesidir” şeklinde tarif etmiştir (1981, s. 354). ${ }^{14}$ Kaçarlar, kendilerinden önceki hanedanların başvurduğu bir yöntemi, meşrûiyet iddialarını takviye etmek için daha etkin biçimde kullanmışlardır.

\section{Kaçarlar ve Taziye}

Kashani-Sabet'e göre (1999, s. 4, 24), İran'da millet olma hikâyesi toprak kayıplarıyla sonuçlanan ve nüfus hareketlerine sebep olan 1804 İran-Rus Savaşı’ndan itibaren başlamıştır. Sınır ile toprak kavramlarının önemine işaret eden Kashani-Sabet, Osmanlılara karşı verilen mücadele ve Anglo-İran Savaşı (1856-57) da hesaba katıldığında, dış güçlere karşı söz konusu kavramların savunulmasının, "İran milleti”nin tanımlanması ve kurgulanmasında önemli bir işlev gördüğünü

12 Safevilerin yönetme haklarının meşrû olduğunu ispatlamak için kullandıkları argümanların başında, Ehl-i Beyt'e mensubiyet iddiası gelmektedir. Daha evvelki kaynaklarda bunu ispatlayan herhangi bir ibare bulunmamasına rağmen; Şah İsmail'in dedesi Şeyh Cüneyd'ten (ö. 1460) itibaren Safevi ailesi kendisini Hz. Ali soyundan göstermeye çalışmış, kaynaklarında buna yer vermiştir (Sümer, 1999, s. 2).

13 Ancak yine de vurgulamak gerekir ki: "Milliyetçilik, geç dönem Kaçar şahları tarafindan iktidarın otoritesini sağlamak amacıyla ideolojik bir iddia olarak asla kullanılmamıştır. Fakat İran devletini üzerine yeniden kuracakları yeni varsayımlar, millet hayal edilebilecek bir kapsamin belirlenmesinde gerekliydi" (Marashi, 2008, s. 12).

14

Şî̂lik ile Sünnîlik arasındaki ayrışmanın en önemli nedeni, Sünnîlerin Hz. Peygamber'in vefatından sonra halifenin seçimle belirlenmesi gerektiğini iddia etmeleri, Şî̂lerin ise halifenin Peygamber’e kan bağıyla bağlı olması gerektiğini savunmalarıdır. Ayrıca, İran kaynaklarında, Hz. Hüseyin’in son Sasani Kralı Yezdgird'in kızı prenses Şehr-i Bânu ile evlendiği iddia edilmiştir. Bununla birlikte, Kerbelâ sonrası Peygamber soyundan geriye kalan tek ardılın Hz. Hüseyin'in hasta olduğu için savaşa katılmamış oğlu Zeynü’l Abidin olması, şecerenin onunla devam etmesi gerektiği yorumunu beraberinde getirmiştir. Bu yolla, İranlılar, İran yönetimlerini Hz. Ali soyuyla (dolayısıyla Hz. Peygamber'le) irtibatlandırmakta önemli bir argüman elde etmişlerdir (And, 2012, s. 102). 
ifade etmektedir. Afshin Marashi ise (2008, s. 5-6); Nationalizing Iran adlı çalışmasında, "İran’ın millîleştirilmesi” hikâyesini XIX. yüzyılın ikinci yarısıyla, yani Nasirüddin Şah dönemiyle (18481896) başlatmaktadır. Marashi’ye göre, XIX. yüzyılın sonları itibarıyla İran artık milliyetçiliği kucaklamaya hazırdı. Çünkü ülkede devlet yapısı ve kültürel formlar değişmeye başlamıştı. ${ }^{15}$

Biz de; Kashani-Sabet ve Marashi'nin sundukları perspektifleri esas alarak, XIX. yüzyıldan itibaren (Kaçar iktidarıyla birlikte) toplumun mevcut yönetime sadakatini ve bir arada yaşama duygusunu artırmaya yönelik araçlar arasına bir Şiî geleneği olan taziyenin alınmasını incelemekteyiz. Yüzyılın ortalarından itibaren, Kaçar yönetiminin merkezdeki gösterilere destek olması ve hatta onları himaye etmesi sayesinde, taziye, kitlelerin yönlendirilmesinde ve kontrol altında tutulmasında önemli bir fonksiyona sahip olmuştur.

Yukarıda belirtildiği gibi, Hz. Hüseyin'in şehit edilmesine dair anmaların İran'da halk arasında popüler dinî içerikle sunulması daha Safevi döneminde (1501-1722) başlamış ${ }^{16}$ ve buna birçok teatral özellik eklenmişti (Mahani, 2013, s. 26). ${ }^{17}$ Fakat söz konusu anmaların organizasyonuna bahse değer bir ivme kazandıran, Kaçarların ikinci temsilcisi Feth Ali Şah (1797-1834) olmuştur. O’nun zamanında, taziye için birkaç sabit alan (tekye) tahsis edilmiştir. Halefi Muhammed Şah (1834-48) dönemindeyse; Sadrazam Hacı Mirza Agasi tarafından, veliaht şehzade, üst düzey devlet görevlileri ve diplomatların düzenli olarak gösterileri izlemeye gittiği görkemli bir tekye inşa ettirilmiştir. Ardından, her yerde ileri gelenlerce yeni tekyeler yaptırılmış ve taziyeye ev sahipliği yapacak yer sayısı hızla artmıştır. 1842-43 yıllarında Tahran'da kalan Fransız bir diplomat, bu kısacık sürede toplam kırk sekiz adet tekye kurulduğunu söylemiştir (Arjomand, 1984, s. 240). Muhammed Şah döneminde ayrıca, Rus ve İngiliz elçileri de gösterilerin daimi izleyicileri haline gelmiştir (Mottahedeh, 2008, s. 77).

Taziyeye verilen önemin doruğa ulaşması Nasirüddin Şah döneminde (1848-96) olmuştur (Arjomand, 1984, s. 240). Bu dönemde, taziye dinî bir ritüelin ötesinde adeta bağımsız bir sanat dalına dönüşmüştür (Mottahedeh, 2008, s. 66). 1856 yılında yayınlanan eserinde Lady Sheil ve 1883-85 yılları arasında iki yıl süreyle İran'da bulunan Amerikalı diplomat S.G.W. Benjamin, gösteriler hakkında detaylı tasvirler sunmuşlardır. Sheil (1856, s. 128), taziyede sahnenin gerçek gibi görünebilmesi için mümkün olan her şeyin yapıldığını ifade etmiş, Benjamin ise (1887, s. 365) onu "çă̆ın en dikkat çekici dinî etkinliklerinden biri” olarak tanımlamıştır.

Mottahedeh (2008), millî reformun gerçekleştirilmesinde tarihsel simgelerin kullanılmasına dair çalışmasında, XIX. yüzyılda söz konusu gösterilere ilginin artışına genişçe yer vermektedir. Bu dönemde, bugün de olduğu gibi, Kerbelâda yaşananlar abartılı biçimde dramatize edilmiş, söz

15 Sonunda bu durum, 1920 ve 30’lara gelindiğinde modern bir ulus-devletin kurulmasını sağlamıştır.

16 Rönesansın en önemli seyyahlarından biri olarak görülen İtalyan Pietro della Valle’nin, XVII. yüzyılın ilk çeyreğinde İsfahan'daki taziye gözlemleri için bkz. (della Valle, 1990, s. 142-145).

17 Kerbelâ temasının, teatral ögelerin yanında Şiîler dışındaki diğer Müslüman toplum edebiyatlarına da geniş yansımaları olmuştur. Mesela kendisi de Kerbelâ yakınlarındaki Hille’de doğan ve hayatının ilk evresinde Safevi tebaasından olup daha sonra Osmanlı tabiiyetine geçen Fuzûli ya da Gelibolulu Mustafa Âli gibi birçok Osmanlı şair ve edibi bu temayı işlemişlerdir. Bkz. (Arslan, 1996, s. 49-67; Fuzulî, 1968; İnalcık, 2016, s. 399). 
konusu ritüel aracılı̆̆ıyla Şiîlik ile Sünnîlik arasındaki temel kırılma hatırlatılıp tekrar tekrar canlandırılmıştır. Bu yolla, İran’ın tarihi "Şî̀” bir "milletin” tarihi olarak kurgulanmış ve "yeniden inşa edilmiştir". Bunun da ötesinde, taziye izleyicilerin gözünde modern bir milletin teorisini üretmiştir (Bkz. s. 10-11, 58).

Tüm Kaçar döneminde tekyelerin inşası ve gösterilerin organizasyonu için önemli miktarda para tahsis edilmiştir. Sadece Tekye-i Devlet' in inşasına ayrılan paranın 150.000 ile 300.000 tümen arasında olduğu tahmin edilmektedir. ${ }^{18}$ Fransız Büyükelçisi, Tekye-i Devlet'te organize edilen taziyenin Şah’a ylllık maliyetinin 1907 yll için 30.000 tümen civarında olduğunu söylemiştir. Üstelik para tahsisi ve diğer destek faaliyetlerine yalnızca Kaçar ailesi değil, başkentte ve vilayetlerdeki bazı elitler de katkıda bulunmuşlardır. Böylece, bir taraftan gerçekleştirilen geleneksel anmalar saray tarafından yeni sembol ile koreografileri içeren bir şekle dönüştürülmüş, diğer taraftan saray sanatı şehirli kalabalıklara açık hale getirilmiştir. Bu durum hem monarşinin hem de gösterileri organize ettiren ileri gelenlerin politik hâkimiyetlerini artırmıştır. Ancak merkezi bölgeler dışındaki halk üzerinde bu hâkimiyetin etkili olduğunu söylemek mümkün değildir. İktidarın himayesindeki gösterilerle, daha çok, başkentte veya doğrudan merkeze bağlı görevlilerin kontrol edebildiği yerlerde yaşayan insanlar ve zaman zaman seyirci olarak davet edilen yabancı diplomatlar etkilenmek istenmiştir (Aghaie, 2004, s. 20-27). ${ }^{19}$

Öte yandan, gösterilerde göğüs dövme (sinezenî) eylemi gerçekleştirilirken Şah’a mersiyeler okunması, iktidarın zihinlerde yüceltilmesi amacına yönelikti. Taziye, seyircilere duygusal boşalma yaşatan emsalsiz etkisiyle potansiyel isyancı hisleri sönümleyen bir araç görevi görmüş, kitlelerin "uysallaştırılması"na katkı sağlamıştır (Arjomand, 1984, s. 241). Ayrıca, toplumun farklı tabakalarından insanların, maddi olarak, kıymetli eşyalarını bağışlayarak veya organizasyonların yerine getirilmesine beden güçleriyle katılarak destek çımaları, taziyeyi insanları bir araya getiren muazzam bir dayanışma projesine dönüştürmüştür (Aghaie, 2004, s. 20). Böylece, diğer sembollerle beraber birlik duygusu vermesi ve farklı etnik kökenden Şiîlerin hepsine ait olmasıyla, bir çeşit "Şiî hayali topluluğu" yaratılmasına hizmet etmiştir. Yani, Hobsbawm’ın (2006, s. 16) "Bütün icat edilmiş gelenekler, mümkün olduğunca grup birlikteliğinin oluşmast ve meşrulaştırılması için tarihe başvururlar" iddiasındaki gibi, Kaçarlar da bu tarihi aracı etkin biçimde kullanmışlardır.

Marashi, Tekye-i Devlet'in inşasının taziyenin dönüşümünü nasıl etkilediğine ve taziyenin oynadığı sosyal fonksiyona vurgu yapmıştır. O’na göre, taziye, sarayda sergilenen özel gösterilerden farklı olarak geleneksel yollarla gelişmiştir. Camilerin ve pazarların yanı başındaki halka açık alanlarda, kişisel mülklerin avlularında, yerel sosyal tesislerde ya da dindarların bağışlarıyla geçici veya sürekli ayakta kalabilen tiyatrolarda sergilenegelmiştir (2008, s. 39-44). Buna karşlık,

18 Harcanan paranın kıyaslanabilmesi açısından Curzon’un sunduğu bazı rakamlar katkı sağlayabilir. Curzon, İran takvimine göre 30 Eylül 1889 tarihinde biten yıl için İran’ın toplam ihracatını 7.442.000 tümen, ihraç malları arasında en büyük paya sahip afyonun değerini ise yaklaşık 1.900.000 tümen olarak tahmin etmiştir (Curzon, 1966 s. 559).

19 Gösterilere yabancı diplomatların davet edilmesi ve bunun bir diplomasi aracı olarak kullanılmasına odaklanan bir ön çalışma için bkz. (Calmard, 1992). 
Nasirüddin Şah döneminde Şah’ın daha ilk yurt dışı seyahatine çıkmasından çok önce, meşhur sadrazam Emir-i Kebir'in sadareti sırasında birkaç bin kişiyi alabilecek büyüklükte bir alan kurulmuş (1849 yılında), taziye metinlerinin zenginleştirilmesi için girişimler başlatılmıştır (Mahjub, 1979, s. 148-151; Peterson, 1979, s. 64-65). 1856'da Niyâverân'da ilk kez “bina” şeklinde bir tekye-i devlet yapılmıştır (And, 2012, s. 218). Ancak, Tahran'daki büyük kompleksin (Tekye-i Devlet'in) yapılmasıyla, taziyeye verilen devlet desteği en somut halini almıştır. Genel bir kullanım da daha ziyade bu özel tesisi tanımlar olmuştur. Yani, tekye-i devlet denildiğinde akla doğrudan Tahran'daki tekye gelmeye başlamıştır. Bundan sonra, aşama aşama gösteriler popüler bir etkinliğe dönüşmüş ve yönetimin tekeline girmiştir (Aghaie, 2004, s. 15-29). Bu anlamda, tekyelerin, özellikle de Tekye-i Devlet'in inşası, 1925 sonrası Pehlevi İranı'nda stadyumların inşa edilmesi ve şehirli kitlelerin kalabalıklar halinde buralara doldurulmasına benzer örneklerin ilki olarak görülebilir (Marashi, 2008, s. 40). Zira Pehlevi hanedanından itibaren, başta futbol olmak üzere çeşitli spor branşları, gösteriler veya konserlerden aynı işlev beklenmiştir. ${ }^{20}$

Diğer taraftan, XIX. yüzyıl ve İran denildiğinde, akla, Rusya ile İngiltere karşısında ağır yenilgilere maruz kalınması, önemli toprak kayıplarının yanı sıra adı geçen iki devletin İran'da ekonomik ve politik nüfûzlarını artırmaları gelmektedir. ${ }^{21} \mathrm{Bu}$ bir taraftan ülkede Avrupa medeniyetine tepkiyi tetiklemiş, diğer taraftan da ilerleme ve Batı Avrupa’nın teknik üstünlüğünü yakalama isteğini ortaya çıkarmıştır (Mensashri, 1992, s. 33). Dönemin İran'da “vatan” ve “millet” gibi kavramların kullanılmaya başladığı bir dönem olması sonucu, Müslüman olmayan Avrupalı devletlere karşı vatanın ve milletin savunulması fikri güçlü dinî söylemle birleşince (Kashani-Sabet, 1999, s. 4774), Şiî İslâm'la tanım bulan modern İran milliyetçiliği gelişmiştir (Lambton, 1988, s. 199). Ancak yine de; her ne kadar İran'da milliyetçi unsurların ilk örnekleri Nasirüddin Şah döneminde ortaya çıkmışsa da bu dönem modern İran milliyetçiliği için daha ziyade bir hazırlık sürecidir. Dönemi, devletin toplum karşısındaki rolünün değiştiği dönem olarak nitelendirmek daha uygundur. Nasirüddin Şah, Avrupa monarşilerinin emperyal-otokrat yöntemlerini uygulayarak kendi monarşisini yeni bir imajla sunmaya gayret etmiş, bunu yaparken de iktidarının meşrûiyetini sağlayacak yeni sembol ile seremonilerden gittikçe daha fazla yararlanmıştır (Marashi, 2008, s. $5,135-136)$.

Taziyeyle ilgili değinilmesi gereken bir diğer husus, Şiî ulemanın gösterilere karşı tutumunun farklı olmasıdır. Abrahamian’a göre (2014, s. 23); "Yaşlıca din adamları böyle gösterileri yakışıksız, kışkırtıcı bulur, belki daha da önemlisi kendi alanlarına el uzatıldığını düşünerek uzak dururlardı.”. Esasen Şiî ulema, taziyeyi, Kur’an'da, hadis ve sünnette veya imamların öğretilerinde yer

20 Sporun toplumsal hayattaki işlevi ve ortaya çıktığı halden nasıl bir şekle dönüştüğü hakkında şu iki çalışmaya bakılabilir: Huizinga, J. (2013) Homo Ludens: Oyunun Toplumsal İşlevi Üzerine Bir Deneme, (çev. Mehmet Ali Kılıçbay), İstanbul: Ayrıntı Yayınları; Guttmann, A. (2006) From Ritual to Record: The Nature of Modern Sports, New York: Columbia University Press.

21 Rusya ve İngiltere’nin bu dönemde İran üzerindeki etkisine dair bkz. Amanat, A. (1993) "Russian Intrusion into the Guarded Domain: Reflections of a Qajar Statesman on European Expansion”, Journal of the American Oriental Society, Vol. 113, No. 1 (Jan.-Mar.): 35-56; Stebbins, H. L. (2012) "British Imperialism, Regionalism, and Nationalism in Iran, 1890-1919”, in Abbas Amanat and Farzin Vejdani (eds.), Iran Facing Others Identity Boundaries in a Historical Perspective, New York: Palgrave Macmillan, 153-172. 
almayan popüler bir uygulama olarak görmüştür. Bu nedenle, çoğu zaman iktidarlar gibi onu doğrudan desteklememiştir. Ulemanın üst mertebelerinde bulunan birinin gösterilere destek olması gibi bir durumla nadiren karşılaşılmıştır. Ancak yine de; onu açıkça yasaklamamış veya doğrudan karşı çıkmamışlardır. Ara sıra, Ayetullah Fazlullah Nuri gibi ulemanın önde gelenlerinden bazıları gösterileri himaye etmiş, kendi hanelerinde düzenletmiştir (Aghaie, 2004, s. 18). Dolayısıyla, ulema taziyeye yaklaşımında kararsız ve bölünmüş kalmıştır. Bunun sebebi, belki de tüm ulema grubunun organik bağının henüz merkezi olmamasıyd. Müctehidlerden taziyenin sergilenmesine karşı olanlar, gösterilere katılan ya da destekleyen din adamlarını kontrol edebilecek bir mekanizmaya sahip değillerdi (Arjomand, 1984, s. 240). Yani, ulemanın yeterince güçlenmemiş ve bağımsız bir güç odağı oluşturamamış olması dünyevî iktidarın elini rahatlatmıştır. ${ }^{22}$ Böylece, Wills’in de ifade ettiği gibi, bu köklü geleneğe bağlılık ciddi bir karşı çıkış olmadan devam etmiştir (1891, s. 283).

\section{Sonuç}

Kaçarlar, Safevi Devletỉnin dağılmasından (1722) sonraki yaklaşık yetmiş beş yıllık otorite boşluğunun ardından İran'da kontrolü sağlamışlardı. XVIII. yüzyıl sonunda tahta sahip olan bu hanedanın yapması gereken ilk iş, merkezi otoritenin yeniden sağlanmasıydı. Ancak, Safevilerin aksine peygamber soyundan geldikleri iddiasında bulunmamışlar, seleflerine meşrûiyet sağlayan bir gerekçeden açıkça mahrum kalmışlardı. Gerçi kendilerini tıpkı Osmanlı Padişahları ve önceki İran iktidarları gibi “Allahin yeryüzündeki gölgesi (zillu'llâhifi'l-arz)” olarak sunmuşlardı. Fakat bu tek başına yeterli değildi. İkincisi, XIX. yüzyılın başından itibaren İran’ın toprak bütünlüğü yabancı güçler tarafından tehdit ediliyordu. Önce Rus, ardından da İngiliz yayılmacılığı İran kapılarına dayanmıştı. $\mathrm{Bu}$ ise dış tehlikeye karşı toplumun konsolide edilmesini, tebaanın birlik haline getirilmesini ve yabancıların gözünde iktidarı elinde bulunduranların saygınlı̆̆ının artırılmasını zorunlu kılıyordu. Bundan ötürü, Kaçarlar, otoritelerini pekiştirmek ve iktidarlarının "meşrû" olduğunu ispatlamak zorunluluğuyla karşı karşıya kaldılar. Bunun için aralarında Şiî kültüründe artık iyice yerleşmiş olan taziye gösterileri de bulunan bir dizi sembol ile araca başvurdular.

Bu çalışmada, Hobsbawm ve Anderson’ın argümanlarından yola çıkılarak taziye gösterilerinin Kaçarlar döneminde İran'da meşrûiyeti sağlamada nasıl kullanıldığı incelenmiştir. Kaçar şahları, özellikle de Nasirüddin Şah, artan iç ve diş tehditlere paralel olarak taziye gösterilerine ve gösterilerin düzenleneceği tekyelerin yapılmasına büyük önem vermişlerdir. Bu kapsamda, taziyeye devlet desteği verilmesi (hatta daha da öte, gösterilerin organizasyonunun himaye altına

22 Şia içinde XVIII. yüzyılda başlamış olan Ahbarî ve Usulî okulları arası tartışma XIX. yüzyılda yeniden alevlenmişti. Bu nedenle, bu yüzyıl Şiî ulemanın bir anlamda hala çok başlı olduğu bir yüzyıldır. Bununla birlikte, ulemanın daha güçlü olması gerektiğini savunan ve Mehdî gelinceye kadar hukuk ve doktrinlerin uygulanması için geçici bir dinî öndere ihtiyaç olduğunu savunan Usulîler, Kaçar Dönemi’nde güçlerini artırabilmişlerdi. Ulema, yüzyılın başından itibaren ilk olarak dinî vergilerin toplanması hakkını "Saklı İmam adına” elde etmiş, ardından 1811-1813 İran-Rus Savaşı sırasında bunu kazanıma dönüştürmüştür. Ulemanın İran’da toplumu yönlendirme gücünün gerçek anlamda test edildiği ve bunun ne denli büyük olduğunun anlaşıldığı olay ise 1890-92 Tütün Protestosudur. Buradan alınan güçle toplum üzerindeki etki genişletilmiş, daha sonraki Meşrûtiyet Hareketi’yle (1906) daha da agresifleşilmiştir. Bkz. (Keddie, 1972, s. 222-225; Lambton, 1988, s. 223-276). 
alınarak icrasına devam edilmesi), bir taraftan taziyenin değişmesini sağlamış, diğer taraftan da yönetime toplumu istediği şekilde yönlendirebilme imkânı vermiştir.

Taziye senaryolarının temelinde, Yezid ile sembolize edilen baskı ve tiranlı̆̆ın dışında, Hz. Hüseyin ile somutlaştırılan başkaldırı ve ıstırap bulunmaktadır. Kahraman ve kötü karakterleriyle taziyenin olay örgüsü, izleyicilerin zihninde sık sık gerçek zamana dair yorumlara yol açmıştır. Tabii ki kahramanlar rakiplerine karşı mücadele eden dönemin İranlı Şî̂leri olarak kimlik bulmuşlardır. XIX. yüzyıl özelinde, Yezid ve ordusu bazen Osmanlıları temsil etmiş, bazense günün şartlarına göre İngilizler veya Ruslara bu vasıf yüklenmiştir. Bu arada, Hz. Hüseyin ve taraftarları gibi görülen doğal olarak Kaçar ordusu olmuştur. Böylelikle, taziye, toplumu diş güçlere karşı birleştiren bir işlev görerek, halka; Şah’a ve yönetime karşı görevlerini hatırlatmıştır.

Diğer yandan, bu yas ritüeli, İran kültürü, edebiyatı ve tarih algısı tarafından biçimlendirilmiş, ayırt edici biçimde İran’a has özellikler içererek buradaki insanların kolektif hafızalarını yansıtmıştır. İran anlatılarında Hz. Ali’nin hakkının gasp edildiğine ve Hz. Hüseyin'in son Sasani hükümdarının kızıyla evlendiğine inanılmasının yanı sıra Emevilere (Araplara) kin duyulması, Kerbelầyı önce Fars sonra da İranlı kimliğinin oluşmasında önemli bir araç haline getirmiştir. Kerbelâ anmaları, şehirli kalabalıklardan oluşan izleyicilerine Şiîlik ile Sünnîlik arasındaki temel kırılmayı hatırlatmış, İran'daki Şîilerin dinî ve “millı̂” duygularını hareketlendirmiştir. Bu anlamda, Kaçar döneminde yönetimin taziyeyi korumasının ve teşvik etmesinin, İran milliyetçiliğinin gelişmesindeki unsurlardan biri olduğu söylenebilir. 1850’lerden itibaren devlet desteği ve himayesiyle düzenlenen taziye gösterileri sayesinde, Şiî bir kamuoyu oluşturmak suretiyle "Şiî dinî kimliği” ile "Şî̂ milleti”" tekrar tekrar uyarılmıştır. Aktörlerle seyirciler arasındaki katılımcı ilişkisinin etkisiyle, "İranlı, Şiî bir cemaat" hayal edilmiştir. 


\section{Kaynakça}

Abrahamian, E. (2014) Modern İran Tarihi, (çev. Dilek Şendil), İstanbul: Türkiye İş Bankası Yayınları.

Aghaie, K. S. (2004) The Martyrs of Karbala: Shi'i Symbols and Rituals in Modern Iran, Seattle and London: University of Washington Press.

Amanat, A. (1993) "Russian Intrusion into the Guarded Domain: Reflections of a Qajar Statesman on European Expansion", Journal of the American Oriental Society, Vol. 113, No. 1 (Jan.-Mar.): 35-56.

And, M. (2012) Ritüelden Drama: Kerbelâ-Muharrem-Ta'ziye, İstanbul: Yapı Kredi Yayınları.

Anderson, B. (1984) Imagined Communities: Reflections on the Origin and Spread of Nationalism, London and New York: Verso.

Arjomand, S. A. (1984) The Shadow of God and the Hidden Imam, Chicago and London: The University of Chicago Press.

Arjomand, S. A. (2016) The State(s) of Ideology in Iran, (29 February 2016), Online (24 February 2017), http://www.washingtoninstitute.org/policy-analysis/view/the-states- of-ideology-in-iran.

Arslan, M., İ. H. Aksoyak (1996) “Gelibolulu Mustafâ Âlînnin Kerbelâ Mersiyelerini Muhtevî Bir Risâlesi: Subhatü’l Abdâl”, Türklük Bilimi Araştırmaları, 2: 49-67.

Asani, A. S. (2015) “Devotional Practices", in Farhad Daftary, Amyn B. Sajoo and Shainool Jiwa (eds.), The Shi $i$ i World: Pathways in Tradition and Modernity, London-New York: I.B. Tauris, 150-168.

Ateş, A. (1987) “Hüseyin”, İslâm Ansiklopedisi, C. 5/1, İstanbul: Millî Eğitim Basımevi, 634-640.

Banani, A. (1961) The Modernization of Iran: 1921-1941, Stanford: Stanford University Press.

Beeman, W. O. (2015) "Religion and Ritual Performance", in Jean-Marie Pradier (ed.), La croyance et le corps. Esthétique, corporéité des croyances et identités, Bordeaux: Presses Universitaires de Bordeaux, 35-58.

Benjamin, S. G. W. (1887) Persia and Persians, London: John Murray.

Bozorgnia, Z. (1383) “Takieh va Hoseinieh”, Neşriyat-ı Mi’mar, No. 27 (Mihr va Âban), Online (13 Mayıs 2017). http://www.zohreh-bozorgnia.com/fa/index.php/takiehvahoseinieh

Calmard, J. (1992) "Muharram Ceremonies and Diplomacy (A Preliminary Study), in F. Bosworth and C. Hillenbrand (eds.), Qajar Iran: Political, Social, and Cultural Change (1800-1925), California: Mazda Publishers, 213-228.

Chelkowski, P. J. (1985) “Shia Muslim Processional Performances”, The Drama Review, No. 29 (Autumn): 18-30.

Curzon, G. N. (1966) Persia and the Persian Question, Vol. 2, London: Frank Cass \& Co. Ltd.

Daniel, E. L., A. A. Mahdi (2006) Culture and Customs of Iran, Westport, Connecticut and London: Greenwood Press.

della Valle P. (1990) The Pilgrim: The Travels of Pietro della Valle, Translated, Abridged and Introduced by George Bull, London, Sydney, Auckland and Johannesburg: Hutchinson.

Deringil, S. (2009) 'Osmanlı İmparatorluğu’nda 'Geleneğin İcadı', 'Muhayyel Cemaat' ('Tasarlanmış Topluluk') ve Pan-İslâmizm”, içinde Simgeden Millete: II. Abdülhamid'den Mustafa Kemal’e Devlet ve Millet, İstanbul: İletişim, 19-51.

Elling, R. C. (2013) Minorities in Iran: Nationalism and Etnicity After Khomeini, New York: Palgrave Macmillan.

Fisher, M. M. J. (1980) Iran: From Religious Dispute to Revolution, Cambridge, Massachussets and London: Harvard University Press.

Fuzulî (1968) Saadete Ermişlerin Bahçesi (Hadikatüssade), İstanbul: İstanbul Maarif Matbaası.

Gnoli, G. (1989) The Idea of Iran: An Essay on its Origin, Serie Orientale Roma (62), Leiden: E.J. Brill. 
Gurney, J. (1992) “The Transformation of Tehran in the later 19th Century", in Chahryar Adle and Bernard Hourcade (eds.), Teheran: Capitale Bicentenaire, Tahran, 51-71.

Guttmann, A. (2006) From Ritual to Record: The Nature of Modern Sports, New York: Columbia University Press.

Hobsbawm, E. J. (1993) 1780'den Günümüze Milletler ve Milliyetçilik: "Program, Mit, Gerçeklik”, (çev.: Osman Akınhay), İstanbul: Ayrıntı.

Hobsbawm, E., T. Ranger (Der.) (2006) Geleneğin İcadı, (çev. Mehmet Murat Şahin), İstanbul: Agora Kitaplı̆̆1.

Huizinga, J. (2013) Homo Ludens: Oyunun Toplumsal İşlevi Üzerine Bir Deneme, (çev. Mehmet Ali Kılıçbay), İstanbul: Ayrıntı Yayınları.

İnalcık, H. (2016) Has-bağçede 'ayş-u tarab: Nedîmler-Şaîrler-Mutrîbler, İstanbul: İş Bankası Kültür Yayınları.

Kamrava, M. (1990) Revolution in Iran: The Roots of Turmoil, London and New York: Routledge.

Kashani-Sabet, F. (1999) Frontier Fictions: Shaping the Iranian Nation, 1804-1946, New Jersey: Princeton University Press.

Keddie, N.R. (1972) “The Roots of the Ulema’s Power in Modern Iran”, in N.R. Keddie (ed.), Scholars, Saints and Sufis: Muslim Religious Institutions in the Middle East since 1500, Berkeley, Los Angeles and London: University of California Press.

Kılıç, Ü. (2013) "Yezîd I", Türkiye Diyanet Vakfı İslâm Ansiklopedisi, C. 43, İstanbul, 513-514.

Kiren, A. (2017) II. Abdülhamid Dönemi Pan-İslâmist Uygulamaları Ekseninde Osmanlı-İran İlişkileri, (Yayınlanmamış Doktora Tezi), İstanbul: İstanbul Üniversitesi Sosyal Bilimler Enstitüsü.

Lady Sheil (Mary Leonora Woulfe) (1856) Glimpses of Life and Manners in Persia, London: John Murray.

Lambton, Ann K.S. (1988) Qajar Persia, Austin, Texas: University of Texas Press.

Marashi, A. (2008) Nationalizing Iran: Culture, Power, and the State, 1870-1940, Seattle and London: University of Washington Press.

Mahani, M. A. N. (2013) The Holy Drama: Persian Passion Play in Modern Iran, Amsterdam and Haren: Leiden University Press.

Mahjub, M. J. (1979) "The Effect of European Theatre and the Influence of its Theatrical Methods upon Ta'ziyeh", in Peter J. Chelkowski (ed.), Ta'ziyeh: Ritual and Drama in Iran, New York: New York University Press and Soroush Press, 137-153.

Matin-Asgari, A. (2012) “The Academic Debate on Iranian Identity: Nation and Empire Entangled”, in Abbas Amanat and Farzin Vejdani (eds.), Iran Facing Others Identity Boundaries in a Historical Perspective, New York: Palgrave Macmillan, 173-192

Mensashri, D. (1992) Education and the Making of Modern Iran, Ithaca and London: Cornell University Press.

Mottahedeh, N. (2008) Representing the Unrepresentable: Historical Images of National Reform from the Qajars to the Islamic Republic of Iran, Syracuse, New York: Syracuse University Press.

Neuman, A. J. (2006) Safavid Iran: Rebirth of a Persian Empire, London-New York: I.B. Tauris.

Özkırımlı, U. (1999) Milliyetçilik Kuramları: Eleştirel Bir Bakış, İstanbul: Sarmal Yayınevi.

Pettys, R. A. (1981) “The Ta’zieh: Ritual Enactment of Persian Renewal”, Theatre Journal, 33(3): 341-354.

Peterson, S. R. (1979) “The Ta'ziyeh and Related Arts”, in Peter J. Chelkowski (ed.), Ta'ziyeh: Ritual and Drama in Iran, New York: New York University Press and Soroush Press, 64-87. 
Rahimi, B. (2013) “Takkiyeh Dowlat: The Qajar Theater State”, in Staci Gem Scheiwiller (ed.), Performing the Iranian State: Visual Culture and Representations of Iranian Identity, New York: Anthem Middle East Studies, 55-71.

Saleh, A. (2013) Ethnic Identity and the State in Iran, New York, Palgrave Macmillan.

Stebbins, H. L. (2012) "British Imperialism, Regionalism, and Nationalism in Iran, 1890-1919", in Abbas Amanat and Farzin Vejdani (eds.), Iran Facing Others Identity Boundaries in a Historical Perspective, New York: Palgrave Macmillan, 153-172.

Sümer, F. (1999) Safevi Devletinin Kuruluşu ve Gelişmesi’nde Anadolu Türkleri’nin Rolü, Ankara: TTK Basımevi.

Tusli, M. 1366 "Hoseiniehha, Tekaya, Masliha”, içinde Muhammed Yusuf Keyani (Haz.), Ketâb-ı Mimari-i İran: Dovre-i İslâmi, Tehran: Çaphâne- i İrşâd-1 İslâmi.

Wills, C. J. (1891) In the Land of the Lion and Sun or Modern Persia, London, New York and Melbourne: Ward, Lock and Co. 